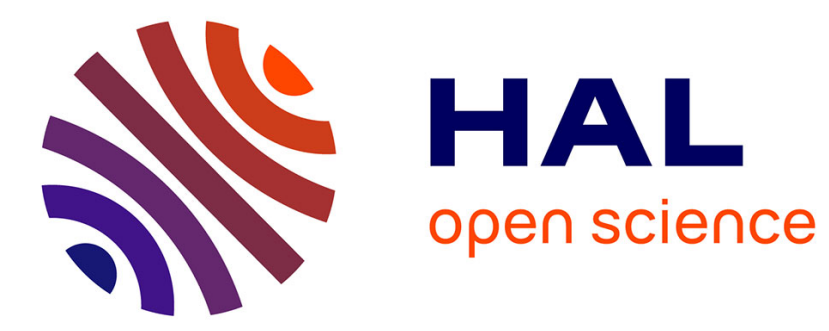

\title{
Monolithic Magnetic Modules for DC-DC Power Converters
}

\author{
U. Varshney, B. Davis Eichelberger Iii, J. Neal, R. Churchill, K. Ngo, R.
}

Thibodeaux

\section{To cite this version:}

U. Varshney, B. Davis Eichelberger Iii, J. Neal, R. Churchill, K. Ngo, et al.. Monolithic Magnetic Modules for DC-DC Power Converters. Journal de Physique IV Proceedings, 1997, 07 (C1), pp.C1147-C1-148. 10.1051/jp4:1997151 . jpa-00255098

\section{HAL Id: jpa-00255098 https://hal.science/jpa-00255098}

Submitted on 1 Jan 1997

HAL is a multi-disciplinary open access archive for the deposit and dissemination of scientific research documents, whether they are published or not. The documents may come from teaching and research institutions in France or abroad, or from public or private research centers.
L'archive ouverte pluridisciplinaire HAL, est destinée au dépôt et à la diffusion de documents scientifiques de niveau recherche, publiés ou non, émanant des établissements d'enseignement et de recherche français ou étrangers, des laboratoires publics ou privés. 


\title{
Monolithic Magnetic Modules for DC-DC Power Converters
}

\author{
U. Varshney, B. Davis Eichelberger III, J.A. Neal III, R.J. Churchill, K.D.T. Ngo* and R.J. Thibodeaux** \\ American Research Corporation of Virginia, 1509 Fourth Street, Radford, Virginia 24143-3406, U.S.A. \\ * Department of Electrical Engineering, University of Florida, Gainesville, Florida 32611-6200, U.S.A. \\ ** U.S. Department of the Air Force, Building 18B, 1950 C Street, Wright-Patterson AFB, \\ Ohio 45433-7251, U.S.A.
}

\begin{abstract}
Advances in planar magnetic technology have resulted in the development of high speed, high power density, magnetic components for use in electrical power converters. In particular, the use of such components will result in a substantial reduction in transformer and inductor volumes, and will encourage development of low-profile, lightweight, efficient power converters that conform readily to printed circuit topologies. This paper describes a single, plasma-spray fabrication process, which overcomes many of the problems associated with integration of components produced by multiple manufacturers. The feasibility of monolithic magnetic technology has been shown by integrating all the magnetic components of a $100 \mathrm{Watt}, 1 \mathrm{MHz}$, DC-DC forward converter into a single, monolithic, non-magnetic module, $51 \mathrm{~mm} \times 51 \mathrm{~mm} \times 5 \mathrm{~mm}$. The process involves plasma deposition of variable-permeability, ultra-low-loss, substituted ferrites that serve as cores for magnetic components. Nonmagnetic regions of the modules serve as windings windows, inductor air gaps, isolations or as mounting substrate for other system components. The significance of the technology is its compatibility with semiconductor integrated circuitry, increased volumetric package efficiency, and reduction of overall manufacturing cost, size and weight of power electronic systems.
\end{abstract}

\section{INTRODUCTION}

Recent advances in planar magnetic technology encourage the development of low-profile, reduced-volume, lightweight, efficient, magnetic components operating at high speeds and high power densities for advanced electrical power system applications. At present, the volume of the best available commercial power converter exceeds that occupied by all other electronic components used in power electronic systems. Conventional inductors and transformers are usually near cubical in shape and are commonly fabricated as separate structures that, when assembled, lower the package volumetric efficiency and do not easily conform to printed circuit topologies. In addition, in a conventional power electronic or electrical power system, the magnetic components are usually fabricated by different manufacturers, thereby leading to duplication of manufacturing resources and efforts and resulting in lack of overall cost effectiveness. This paper addresses the need for planar, low-profile, high density, efficient, high performance magnetic components compatible with semiconductor integrated circuit technology, and reports the feasibility of monolithic magnetic technology by integrating all the magnetic components of a $100 \mathrm{~W}, 1 \mathrm{MHz}$, DC-DC forward converter into a single monolithic non-magnetic module, $51 \mathrm{~mm} \times 51 \mathrm{~mm} \times 2.5 \mathrm{~mm}$, using a single plasma spray fabrication process. The plasma spray technique has the distinct capability of eliminating component machining, usually a cumbersome process that degrades the material properties and creates material wastage associated with the fabrication of netshape ferrites. The technique involves the deposition of variable-permeability, ultra-low-loss, substituted nickel (Ni) and manganese $(\mathrm{Mn})$ ferrites that serve as cores for magnetic components, while the non-magnetic regions of the modules serve as windings windows, inductor air gaps, isolations or mounting substrate for other system components.

\section{RESULTS AND DISCUSSION}

This section presents and discusses the results of an experimental program for the fabrication of monolithic magnetic modules of magnetic components from variable-permeability, ultra-low-loss, substituted $\mathrm{Ni}$ and $\mathrm{Mn}$ ferrite thick film core geometries using the plasma spray process for the development of planar, low-profile, efficient, reliable, high performance, high density DC-DC power converters operational at $1 \mathrm{MHz}$ with power density of $6.1 \mathrm{~W} / \mathrm{cm}^{3}\left(100 \mathrm{~W} / \mathrm{in}^{3}\right)$ and power rating of $100 \mathrm{~W}$. Plasma spraying was performed under atmospheric conditions using a plasma flame spray system. Figure 1 shows a circuit diagram incorporating magnetic components, such as power transformer, current-sense transformer, gate-drive transformer and filter inductors, of a $100 \mathrm{~W}, 1 \mathrm{MHz}, \mathrm{DC}-\mathrm{DC}$ power converter [1]. Figure 2 shows a photo-micrograph of an equivalent plasma-sprayed, monolithic non-magnetic module, incorporating all the magnetic components of a $100 \mathrm{~W}, 1 \mathrm{MHz}, \mathrm{DC}-\mathrm{DC}$ 
power converter integrated in one planar structure. The monolithic magnetic module is a planar, low-profile (less than $5 \mathrm{~mm}$ thick) non-magnetic substrate that incorporates several magnetic and non-magnetic regions. The magnetic regions, shown as dark-shaded areas, consist of variable permeability, ultra-low-loss ferrites as required by the magnetic components. The nonmagnetic regions, shown as light-shaded areas, serve as windings windows, inductor air gaps, isolations, or mounting substrate areas for other system components. Preliminary magnetic material property requirements and design parameters, for the magnetic components of a one-transistor, $100 \mathrm{~W}, 1 \mathrm{MHz}, \mathrm{DC}-\mathrm{DC}$ forward power converter to be developed from a monolithic magnetic module were computed using the procedures described by Ngo [2-3] and by finite element simulation methods published by Maxwell [4]. The preliminary design of the semiconductor components was also evaluated. The results suggested that, for an output power level of $100 \mathrm{~W}$, an overall efficiency of $85 \%$ and an operational frequency of $1 \mathrm{MHz}$, the monolithic module would measure $51 \mathrm{~mm} \times 51 \mathrm{~mm} \times 2.5 \mathrm{~mm}(2.0 \mathrm{in} \times 2.0 \mathrm{in} \times 0.1 \mathrm{in})$ and would dissipate less than $3 \%$ of the output power. The dimensions were chosen to achieve a power density greater than $6.1 \mathrm{~W} / \mathrm{cm}^{3}\left(100 \mathrm{~W} / \mathrm{in}^{3}\right)$.

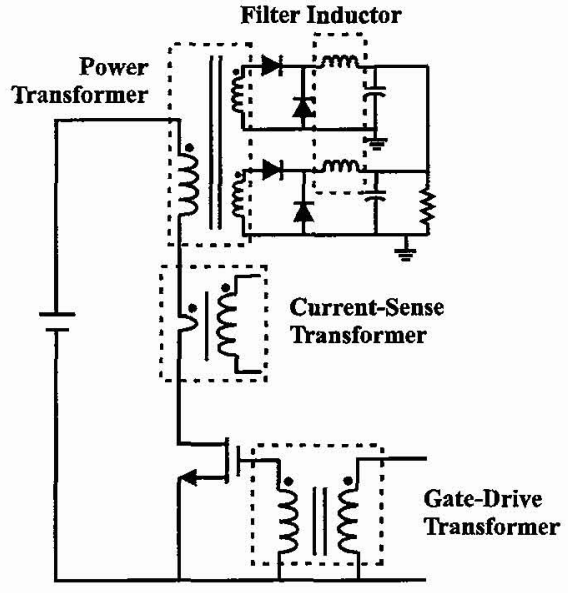

Figure 1: $\quad$ Circuit Diagram of $100 \mathrm{~W}, 1 \mathrm{MHz}, \mathrm{DC}-\mathrm{DC}$ Forward Power Converter.

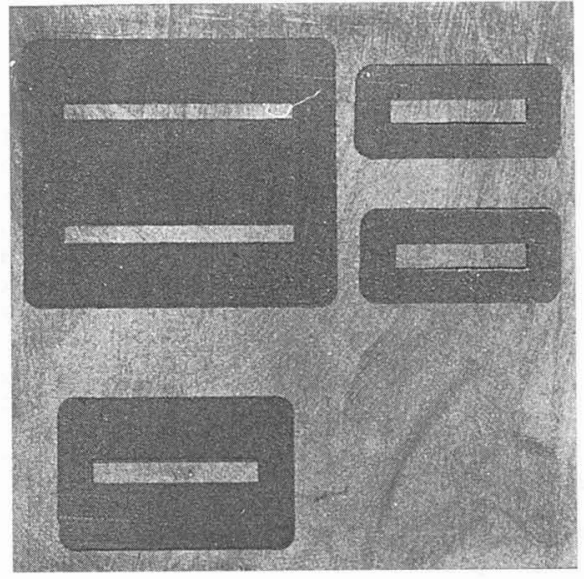

Figure 2: Photo-micrograph of Plasma-sprayed Monolithic Magnetic Module of Forward Power Converter.

Initially toroidal geometry ferrite thick films with outer diameter of $1.8 \mathrm{~cm}$, inner diameter of $0.6 \mathrm{~cm}$ and thickness of $2 \mathrm{~mm}$ were plasma sprayed on non-magnetic substrates and characterized for their metallurgical, electrical and magnetic properties using twenty turns of bifilar winding of 30 SWG Litz wire. The inductive characteristics of toroidal geometry ferrite thick films were evaluated using a Hewlett-Packard Impedance/Gain Phase Analyzer Model 4194A in the frequency range $40 \mathrm{kHz}$ to $40 \mathrm{MHz}$. The zone of utility was determined from the frequency spectrum of permeability and magnetic loss factor. The high flux density magnetic material component properties were determined by exciting the samples with a PM 5192 function generator connected to an ENI 2100L RF amplifier, and measuring the waveforms with a Tektronix 2400 digital storage oscilloscope. The material permeability, which is independent of flux level, was determined from the experimental voltage and current measurements at each frequency [5]. An initial permeability of 10 was observed in the plasma-sprayed, ferrite sample as compared to 20 for the conventional furnace-sintered ferrite over the operational frequency range from $10 \mathrm{KHz}$ to $1 \mathrm{MHz}$. A core-loss density of $200 \mathrm{~mW} / \mathrm{cm}^{3}$ for a flux density of $10 \mathrm{mT}$ at $1 \mathrm{MHz}$ was observed thereby establishing the feasibility of the monolithic magnetic technology. The variation in core-loss density suggests the need for optimization of process parameters for improved device-quality and reproducibility of plasma-sprayed thick films.

\section{Acknowledgments}

This material is based upon work sponsored by U.S. Department of the Air Force under the Contract No. F33615-95-C-2516. The government has certain rights in this material.

\section{References}

[1] Mohan N. Undeland T.M. and Robbins W.P., Power Electronics (John Wiley \& Sons, Inc., New York, 1995$)$ pp. $311-414$.

[2] Ngo K.D.T. Alpizar E. and Watson J.K., IEEE Transactions on Power Electronics 10 (4) (1995) 427-434.

[3] Ngo K.D.T. Alpizar E. and Watson J.K., IEEE Transactions on Power Electronics 8 (2) (1995) 200-207.

[4] Maxwell, 2D Field Simulator User's Reference, (Ansoft Corporation, June 1994) pp. 2-29.

[5] Goldberg, A.F., "High Field Properties of Nickel-Zinc Ferrites at 1-10 MHz," Third Annual IEEE Applied Power Electronics Conference and Exposition, New Orleans, Louisiana, (1988) pp. 311-317. 